Sains Malaysiana 49(7)(2020): 1651-1662

http://dx.doi.org/10.17576/jsm-2020-4907-16

\title{
Foot Over Pronation Problem among Undergraduate Students: A Preliminary Study
}

(Masalah Lebihan Pergerakan Pronat Kaki dalam kalangan Pelajar Prasiswazah: Suatu Kajian Awal)

\author{
Nur Saibah Ghani, Nasrul Anuar AbD RazaK*, Juliana Usman \& H. Gholizadeh
}

\begin{abstract}
Over pronation is a dysfunctional movement where the foot has turned in excessively from its neutral line and can lead to misalignment of the foot and leg in humans. The purposes of this study are to investigate the ankle biomechanics behavior in individuals among the undergraduate students with over pronation foot and provide guidelines to help correct the foot deformities. 10 subjects with over pronated foot where volunteer but only 7 pass the selection test and divided into two group normal subjects $(n=2)$ and over pronated subjects $(n=5)$. Vicon motion analysis was used to observe and analyze the gait cycle and the ankle range of motion in individuals with over pronation. The study found that the ankle joint during the initial contact was below $5^{\circ}$ for all subjects. Subject 2 shows the lowest ankle angle during initial contact while for mid stance phase, subject 3 shows the highest ankle angle which was $24.15^{\circ}$ on left foot and $28.30^{\circ}$ on right foot. From the ANOVA test, the $p$ value for ankle joint angle was less than 0.05 , which indicates that there was significant difference between all the subjects. The ankle angle depended on the muscle movement as the muscles and ligaments tried to stabilize and move the foot by controlling the angle to make sure the foot is in correct position and can move forward. As conclusion, there are significant differences for ankle behavior between normal and over pronated subjects, thus proper guideline for exercise or treatment can help to overcome this problem.
\end{abstract}

Keywords: Ankle joint; deformity; motion analysis; over pronation; range of motion

ABSTRAK

Lebihan pergerakan pronat adalah salah satu masalah kaki bergerak melebihi had yang ditetapkan daripada garisan neutralnya dan boleh menyebabkan ketidaksejajaran pada kaki manusia. Tujuan kajian ini adalah untuk mengkaji tingkah laku biomekanisme buku lali dalam kalangan pelajar-pelajar prasiswazah yang menghadapi masalah buku lali yang terlebih pronat dan memberi panduan untuk membetulkan kecacatan kaki. 10 individu yang menghadapi lebihan pergerakan pronat kaki telah sukarela ingin menyertai kajian ini, tetapi hanya 7 individu sahaja yang lulus dalam ujian pemilihan dan dibahagikan kepada dua kumpulan iaitu individu yang normal $(n=2)$ dan individu yang mempunyai buku lali yang lebih pronat $(n=5)$. Analisis pergerakan Vicon dijalankan untuk memerhati dan menganalisis kitaran gaya berjalan dan pergerakan pada sudut buku lali. Hasil kajian menunjukkan sudut buku lali semasa sentuhan awal adalah di bawah $5^{\circ}$ untuk semua individu. Individu ke-2 menunjukkan sudut buku lali yang paling rendah semasa sentuhan awal untuk fasa pendirian pertengahan, individu ke-3 menunjukkan sudut buku lali yang paling tinggi iaitu $24.15^{\circ}$ pada kaki kiri dan $28.30^{\circ}$ pada kaki kanan. Melalui ujian statistik ANOVA, nilai $p$ untuk sudut buku lali adalah kurang daripada 0.05 dan ini menunjukkan terdapat perbezaan yang ketara antara subjek kajian. Sudut buku lali bergantung kepada pergerakan otot kerana otot and ligamen cuba menstabilkan dan menggerakkan kaki dengan mengawal sudut bagi memastikan kaki berada dalam keadaan stabil dan boleh bergerak ke hadapan. Kesimpulannya, terdapat perbezaan yang ketara terhadap tingkah laku buku lali antara individu normal dan individu yang lebih pronat, dengan itu garis panduan yang betul untuk senaman atau rawatan boleh membantu untuk mengatasi masalah ini.

Kata kunci: Kajian pergerakan; nilai pergerakan sudut; penyakit; sudut buku lali; terlebih pronat

\section{INTRODUCTION}

Pronation is the simultaneous calcaneal eversion with foot abduction and dorsiflexion (Hagen et al. 2018). The range of motion (ROM) for subtalar joint during pronation was around 5 to $10^{\circ}$ (Krähenbühl et al. 2017). Pronation is important for stabilization in standing and walking, but excessive ROM for this motion can lead to over pronation. Koura et al. (2017) stated that postural stability at level four of dynamic balance system was affected by foot pronation. Over pronation is a dysfunctional movement 
where the foot turns in excessively from its neutral line. ROM for over pronation is when it exceeds $5^{\circ}$ of angle from the subtalar neutral position when standing and $15^{\circ}$ when walking. Over pronation causes the foot to enter the stance phase in a position where the surface makes contact with the medial aspect of the foot earlier than normal (Rome \& Brown 2004).

One of the methods to assess over pronation is by measuring the foot arch because it is an important element of posture examination (Bibrowicz et al. 2018). The lower parts of the metatarsals bone are called medial longitudinal arch and during the walking or standing, the body weight will be distributed from the back of the metatarsals to the toe area (Shaliza et al. 2017). Over pronation is associated with low arch condition, also known as flat foot (Golightly et al. 2014). This condition can lead to instability of the subtalar joint due to the decrease of the medial longitudinal arch. In 2017, Sabharwal and Singh concluded that excessive force exerted on the ankle due to repetitive tapping on the floor during dancing can decrease the medial longitudinal arch and flattening of the foot thus leading to unstable subtalar joint. Furthermore, Aguilar et al. (2016) suggested that a pronated foot was related with excessive foot pronation and defined as flattening or loss of the medial longitudinal arch. Excessive internal rotation of the shank with excessive anterior pelvic tilt, also known as altered knee movement and excessive joint stress also happens due to an over pronated foot (Riskowski et al. 2013). The lowering of the arch pulls the heel bone in, which causes the leg, thighbone, and hip to rotate inward to the anterior tilt of the pelvis. These show that over pronation cause pain and dysfunction in humans.

Subtalar joint instability is one of the foot deformities that can causes the foot to be in the position and motion of over pronation and over supination which can lead to various problems including misalignment of the foot and leg in humans. This happens due to acute inversion and internal rotation trauma of the foot (Hintermann 1999). A study by Xiao et al. (2017) concluded that rotation angles of plantar and dorsi flexion affects the rotation ranges of supination and pronation. This will cause looseness and/or giving away of the joint and is associated with ankle instability. According to Krähenbühl et al. (2017), they suggest that subtalar joint instability may occur when there is a malfunction of the interosseous talocalcaneal ligament in combination with failure of the anterior ligament that leads to an abnormal function of the anterolateral rotation of the talus during gait. Calcaneofibular ligament is the main contributor for the stability of the subtalar joint (Ringleb et al. 2011).

The function of the subtalar joint is to allow sideto-side movement of the foot and ankle. The subtalar joint allows for supination and pronation movement (Krähenbühl et al. 2017). This movement aids in walking especially on uneven surfaces. In dealing with activity of daily livings (ADLs), normal humans tend to over pronate and over supinate the joint during walking or running. This can lead to subtalar joint instability and cause deformity and also foot problems, such as abnormality of foot arch, misalignment of the foot, and gait deviation. Kakihana et al. (2015) stated that subjects with laterally shifted center of pressure (CoP) when walking due to the unstable lateral ankle produces a large ground reaction force (GRF) under the lateral aspect of the foot. Furthermore, the stability of the foot will be impaired and can lead to patellofemoral pain, or foot pain, when excessive compensatory pronation of subtalar joint occurs during weight-bearing activity (Shih et al. 2011).

Biomechanical evidence supports that altered lower limb alignment can lead to extremes changes of foot posture and function (Riskowski et al. 2013). Over pronation due to unstable subtalar joint that can lead to injury and chronic functional instability of the foot if no treatment is carried out. Besides that, Mitchell et al. (2008) believes that the unstable subtalar joint will have a slower reaction time to induce ankle sprain mechanism compared to a stable joint. Biomechanical abnormalities in gait can cause inversion sprain which is important in gait and sport (Willems et al. 2005). Therefore, the main objectives of this study were to investigate the ankle biomechanics in individuals among the undergraduate students with over pronated foot and provide proper guidelines in order to correct and prevent foot deformities such as subtalar instability. The study hypothesis is that subjects with over pronated foot will show statistical difference in the ankle biomechanics depending on the foot condition compare with normal subjects.

\section{MATERIALS AND METHODS}

\section{SUBJECT SELECTION}

Ten undergraduate students were recruited to participate in this study but only seven were selected and divided into two groups that are subjects with over pronation condition $(\mathrm{n}=5)$ and normal subjects $(\mathrm{n}=2)$. The numbers of subjects were sufficient to prove the objectives of this study since this study was a preliminary study. If larger sample sizes were recruited it can increase the trial cost and delay the finding results from this study where there was already sufficient evidence that can obtain from the current subjects to prove the objective of this study in which to investigate the ankle biomechanics in individuals among the undergraduate students with over pronated foot and normal foot condition (Suresh \& Chandrashekara 2012). Similar studies by Kosonen et al. (2017) and Wright et al. (2000) used small group of subjects which is 11 subjects and 10 subjects able to prove their objective with their finding results indicated that the small sample size from this study still reliable for the outcomes of this study. 
They were pre-screened for inclusion and exclusion criteria such as: the foot posture index must be positive score for over pronated foot; the medial longitudinal arch angle for over pronated foot must be greater than $152^{\circ}$; and the navicular drop test for over pronated feet must be more than $1 \mathrm{~cm}$. The Foot Posture Index (FPI) is often used in clinical study to analyse the standing foot posture and it is a validated method (Redmond et al. 2008). 6 criterion-based observation of rear foot and forefoot where used that were talar head palpation, curvature at the lateral malleoli, inversion/eversion of the calcaneus, talonavicular bulging, medial longitudinal arch and abduction/adduction of the forefoot on the rear foot. All the criteria were evaluate using scale of ( 0 for neutral 2 for clear signs of supination and +2 for clear signs of pronation) (Lee et al. 2015). All the subjects show FPI more than +7 were selected for the test.

The pre-screening data and demographic data of all the subjects are described in Table 1. All the subjects did not wear any orthotic device to help correct the foot deformities. Subjects also selected based on their activity level, they need to have active lifestyle and mostly need to walk for their daily life activity. All 7 subjects that selected are active college students that involved with many sport activity and walking form the college to the faculty.

TABLE 1. Evaluation of subjects' characteristics

\begin{tabular}{|c|c|c|c|c|c|c|c|c|}
\hline \multirow{2}{*}{\multicolumn{2}{|c|}{ Characteristics }} & Subject 1 & Subject & Subject & Subject 4 & Subject 5 & Mean \pm SD & Median \\
\hline & & & 2 & 3 & & & & \\
\hline \multicolumn{2}{|c|}{ Gender $(\mathrm{M} / \mathrm{F})$} & Female & Male & Female & Female & Male & - & - \\
\hline \multicolumn{2}{|c|}{ Age (years) } & 22 & 22 & 25 & 28 & 25 & $24.4 \pm 2.51$ & 25 \\
\hline \multicolumn{2}{|c|}{ Height (cm) } & 164 & 169 & 151 & 157 & 169 & $162.0 \pm 7.87$ & 164 \\
\hline \multicolumn{2}{|c|}{ Weight (kg) } & 62.0 & 70.0 & 70.0 & 55.5 & 102.5 & $72.0 \pm 18.10$ & 70 \\
\hline \multicolumn{2}{|c|}{ Body mass index (kg/ } & 23.1 & 24.5 & 30.7 & 22.3 & 35.7 & $27.26 \pm 5.76$ & 24.5 \\
\hline \multicolumn{2}{|c|}{ Navicular drop (cm) } & 1 & 1 & 1 & 1 & 1 & $1 \pm 0$ & 1 \\
\hline \multicolumn{2}{|c|}{ Foot posture index (Total Score) : } & +8 & +9 & +8 & +7 & +7 & $7.8 \pm 0.84$ & 8 \\
\hline a) & Talar head palpation & 1 & 1 & 1 & 1 & 1 & & \\
\hline \multirow{2}{*}{ b) } & & 1 & 1 & 1 & 1 & 1 & & \\
\hline & malleoli & 1 & 1 & 2 & 1 & 1 & & \\
\hline \multirow[t]{3}{*}{ c) } & Inversion/eversion of & & & & & & & \\
\hline & the calcaneus & 1 & 2 & 1 & 1 & 1 & & \\
\hline & & 2 & 2 & 2 & 2 & 2 & & \\
\hline d) & talonavicular bulging & 2 & 2 & 1 & 1 & 1 & & \\
\hline e) & Medial longitudinal arch & & & & & & & \\
\hline \multirow[t]{2}{*}{ f) } & $\begin{array}{l}\text { Abduction/adduction of } \\
\text { the forefoot on the rear }\end{array}$ & & & & & & & \\
\hline & foot & & & & & & & \\
\hline
\end{tabular}

*SD: Standard Deviation 
ETHICS

This research was conducted with the approved permission by the National Medical Research Register Secretariat 37912 and under the guidance of Certified Prosthetist and Orthotist (CPO) of the International Society of Prosthetics and Orthotics (ISPO) Category-1.

\section{EXPERIMENTAL SETUP}

All experiments were performed in the video-based motion analysis laboratory. All the kinematic parameters were recorded and captured using five infrared camera and 16 passive reflective sphere markers that were attached to the subjects' lower limb. The kinetic data was determined using two rectangular metal force plates embedded in the floor of the walkway. The software enables the connection to the infrared camera and was used to complete the calibration procedure and analysis of data. The experimental set-up of Vicon Motion Analysis for this study was as in Figure 1.

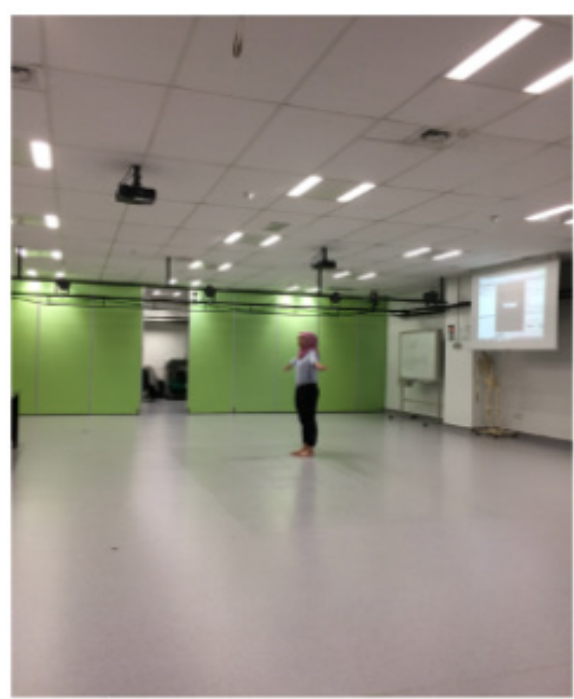

(a)

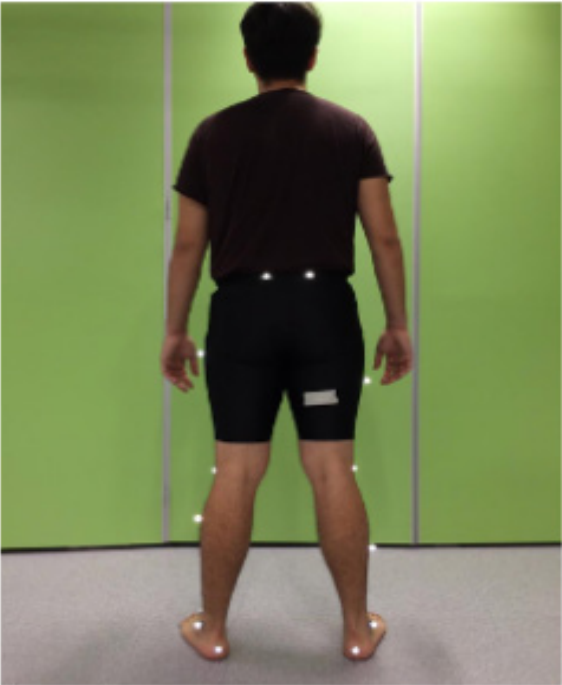

(b)

FIGURE 1. The experimental set-up; (a) The position of the subject during the T-pose procedure, and (b) The 16 passive markers positions on the lower limb of the subject

Each subject was asked to walk on the walkway that had been embedded with two-force plates on the floor. First, the subject was asked to stand in a T-pose position and was recorded. Static plug-in gait analysis was done using the video captured and all the markers were labeled in the system according to the placement location.

Each subject performed three series of Dynamic plug-in gait test which were the self-selected walking speed, low speed walking and high-speed walking. Each test will be repeated five times in order to get the average and the analysis was done by findings the means values for each parameter. The observation was done based on 4 importance phases involving the ankle movement in the gait cycle. Phase 1 is the initial contact (heel strike). Phase 2 is the foot flat position where the ankle then undergoes dorsiflexion. Phase 3 is the heel beginnings to lift at the beginning of the double support followed by phase 4 which is the swing phase.

\section{DATA PROCESSING AND ANALYSIS}

All of the data analysis was done using the Nexus system and ANOVA analysis was done using excel data extracted from the system. The distribution of data was evaluated for normality, reported using means and standard deviation. ANOVA test were performed to evaluate the difference between over pronated foot and normal foot condition. The alpha level was set as $\mathrm{P}<0.05$ as significant value. Parameters were normalized using motion capture system and the graphs were generated using the Polygon report. The MATLAB R2019a and Microsoft Excel software were used to plot the graph and analyze the results. 
RESULTS

The results from the motion analysis test for were translated into Table 2. Results from the over pronated foot were compared to the normal foot in order to observe the difference in the gait pattern. In Table 2, the results will show the ankle angle in 4 different phases (Phase 1-4) and classified into 5 conditions, the peak joint moment, ankle power and GRF values for all the subjects, the display results were the means value \pm standard deviation for each subjects.

TABLE 2. Summary of ankle kinetic data at phases of experimental analysis

\begin{tabular}{|c|c|c|c|c|c|c|c|c|c|c|c|c|c|}
\hline \multicolumn{2}{|c|}{ Parameters } & \multicolumn{2}{|c|}{ Subject 1} & \multicolumn{2}{|c|}{ Subject 2} & \multicolumn{2}{|c|}{ Subject 3} & \multicolumn{2}{|c|}{ Subject 4} & \multicolumn{2}{|c|}{ Subject 5} & \multicolumn{2}{|c|}{ Normal } \\
\hline & & Left & Right & Left & Right & Left & Right & Left & Right & Left & Right & Left & Right \\
\hline & & foot & foot & foot & foot & foot & foot & foot & foot & foot & foot & foot & foot \\
\hline \multirow{16}{*}{$\begin{array}{c}\text { Ankle } \\
\text { Angle }\left({ }^{0}\right) \\
\pm \mathrm{SD}\end{array}$} & Heel strike & -4.02 & -1.01 & -1.24 & 2.23 & 9.59 & 3.66 & -4.86 & 3.54 & -5.33 & -5.25 & -1.29 & -1.29 \\
\hline & & \pm 1.28 & \pm 0.55 & \pm 0.96 & \pm 1.97 & \pm 6.43 & \pm 1.50 & \pm 3.85 & \pm 3.01 & \pm 1.33 & \pm 1.20 & \pm 0.50 & \pm 0.49 \\
\hline & Max. Plantar & -9.61 & -5.39 & -4.26 & -0.57 & 3.98 & -3.91 & -7.01 & 1.68 & -9.25 & 0.56 & -4.13 & -4.11 \\
\hline & flexion in & \pm 2.78 & \pm 1.79 & \pm 1.25 & \pm 0.10 & \pm 1.98 & \pm 8.75 & \pm 3.66 & \pm 0.50 & \pm 0.69 & \pm 0.20 & \pm 1.20 & \pm 1.25 \\
\hline & Loading & & & & & & & & & & & & \\
\hline & Response & & & & & & & & & & & & \\
\hline & Max. & 14.14 & 18.28 & 6.83 & 8.88 & 24.49 & 28.46 & 15.33 & 21.38 & 16.06 & 20.63 & 14.90 & 14.90 \\
\hline & Dorsiflexion & \pm 0.72 & \pm 1.56 & \pm 0.69 & \pm 0.54 & \pm 1.14 & \pm 4.08 & \pm 3.71 & \pm 7.16 & \pm 0.88 & \pm 1.26 & \pm 0.70 & \pm 0.75 \\
\hline & in Stance & & & & & & & & & & & & \\
\hline & phase & & & & & & & & & & & & \\
\hline & Flexion at & -10.8 & -8.86 & -9.38 & -5.49 & -8.18 & -8.19 & -8.21 & -2.48 & -7.46 & 6.81 & -5.91 & -4.32 \\
\hline & toe off & \pm 1.32 & \pm 1.25 & \pm 2.36 & \pm 1.13 & \pm 4.25 & \pm 1.30 & \pm 6.23 & \pm 1.09 & \pm 4.25 & \pm 4.87 & \pm 1.10 & \pm 1.25 \\
\hline & Max. & -26.07 & -23.89 & -23.56 & -22.55 & -16.88 & -23.96 & -20.42 & -8.25 & -17.23 & -1.25 & -13.15 & -19.96 \\
\hline & dorsiflexion & \pm 3.20 & \pm 1.50 & \pm 1.80 & \pm 1.48 & \pm 2.89 & \pm 4.03 & \pm 4.19 & \pm 4.20 & \pm 1.33 & \pm 0.80 & \pm 2.50 & \pm 2.75 \\
\hline & in swing & & & & & & & & & & & & \\
\hline & phase & & & & & & & & & & & & \\
\hline Moment & Peak joint & 1.14 & 1.93 & 1.19 & 1.11 & 1.05 & 0.73 & 1.20 & 1.06 & 0.95 & 0.94 & 1.19 & 1.21 \\
\hline$(\mathrm{Nm} / \mathrm{kg})$ & moment & \pm 0.11 & \pm 0.05 & \pm 0.05 & \pm 0.06 & \pm 0.12 & \pm 0.24 & \pm 0.20 & \pm 0.19 & \pm 0.40 & \pm 0.20 & \pm 0.19 & \pm 0.25 \\
\hline$\pm \mathrm{SD}$ & & & & & & & & & & & & & \\
\hline Power & A1 Region & 0.86 & 1.10 & 0.61 & 0.42 & 0.65 & 0.59 & 0.77 & 0.75 & 0.56 & 0.59 & 3.30 & 2.16 \\
\hline$(\mathrm{W} / \mathrm{kg}) \pm$ & & \pm 0.12 & \pm 0.16 & \pm 0.20 & \pm 0.15 & \pm 0.34 & \pm 0.22 & \pm 0.10 & \pm 0.12 & \pm 0.29 & \pm 0.20 & \pm 1.50 & \pm 1.34 \\
\hline SD & A2 Region & 1.86 & 2.19 & 2.34 & 2.40 & 2.28 & 2.25 & 1.77 & 2.23 & 1.94 & 1.38 & 0.69 & 0.98 \\
\hline & & \pm 0.24 & \pm 0.89 & \pm 0.29 & \pm 0.09 & \pm 1.22 & \pm 1.23 & \pm 0.20 & \pm 0.90 & \pm 1.00 & \pm 0.90 & \pm 0.30 & \pm 0.40 \\
\hline GRF (N/ & First peak & 0.61 & 3.27 & 0.71 & 0.02 & 0.75 & 0.02 & $0.5 \mathrm{~S}$ & 0.04 & 1.05 & 0.03 & 0.76 & 0.01 \\
\hline $\mathrm{kg}) \pm \mathrm{SD}$ & & & & & & & & & & & & & \\
\hline & Second peak & 0.65 & 2.89 & 0.58 & 0.05 & 0.53 & 0.12 & 0.47 & 0.09 & 0.84 & 0.08 & 0.70 & 0.02 \\
\hline
\end{tabular}


The ankle angle movements during one complete gait cycle for both right and left side of the foot were displayed as in Figure 2. While the ankle moment for all subjects was shown as in Figure 3. Each graph will represent the ankle angle and moment for each subject with over pronation condition and normal condition.

The statistical analysis was done to test the null hypothesis that indicates all over pronation subjects will generate the same mean ankle joint angle. The results from this test were interpreted as in Table 3, it will show the $P$-value and Standard error between groups for right and left foot.

There were no significant differences between the groups of normal foot condition and over pronation foot condition for age $(p=0.16)$, height $(p=0.75)$, body mass $(\mathrm{p}=0.45)$ or BMI $(\mathrm{p}=0.46)$.

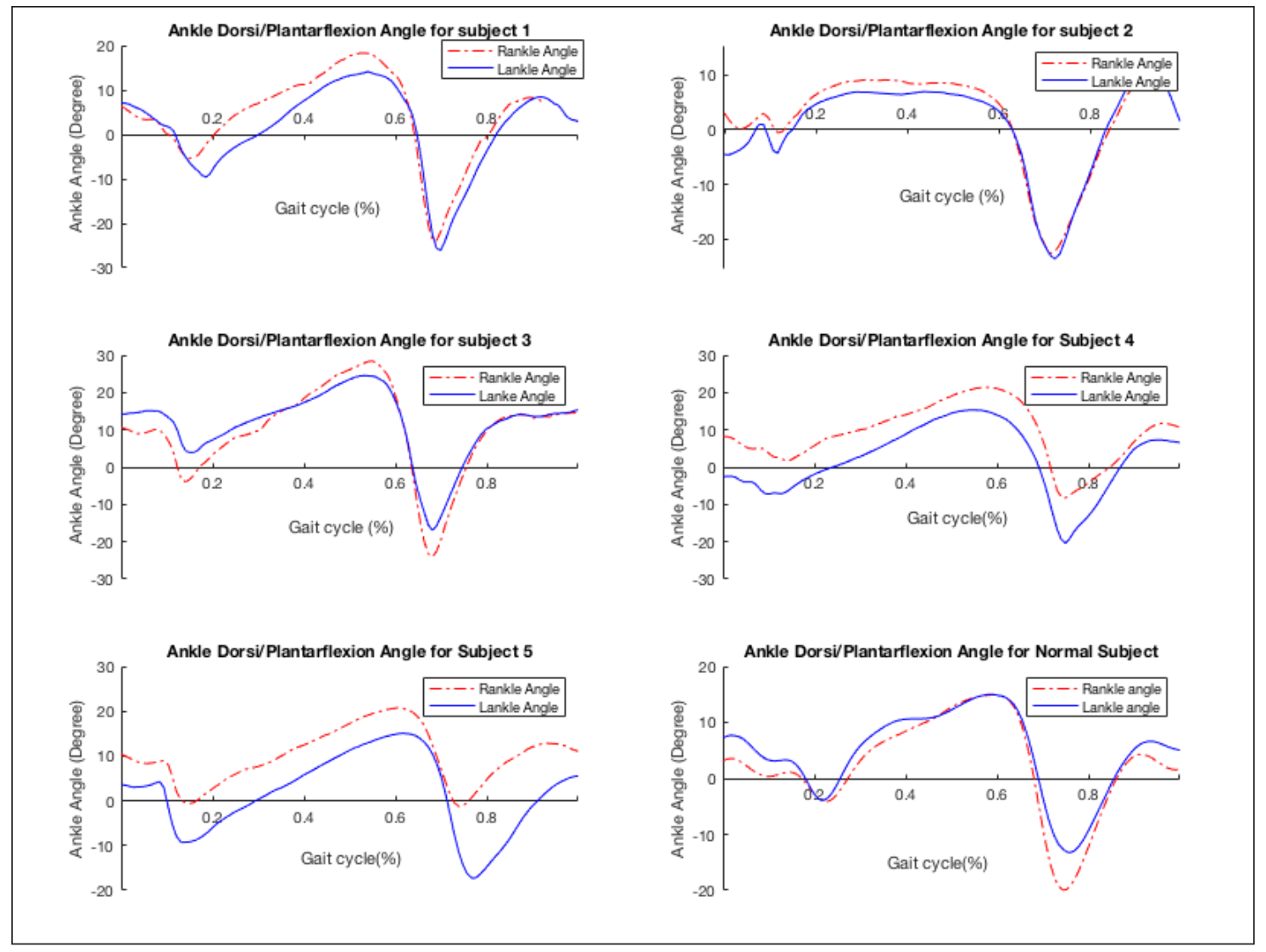

FIGURE 2. Graph of ankle joint angle for a complete gait cycle of all subjects
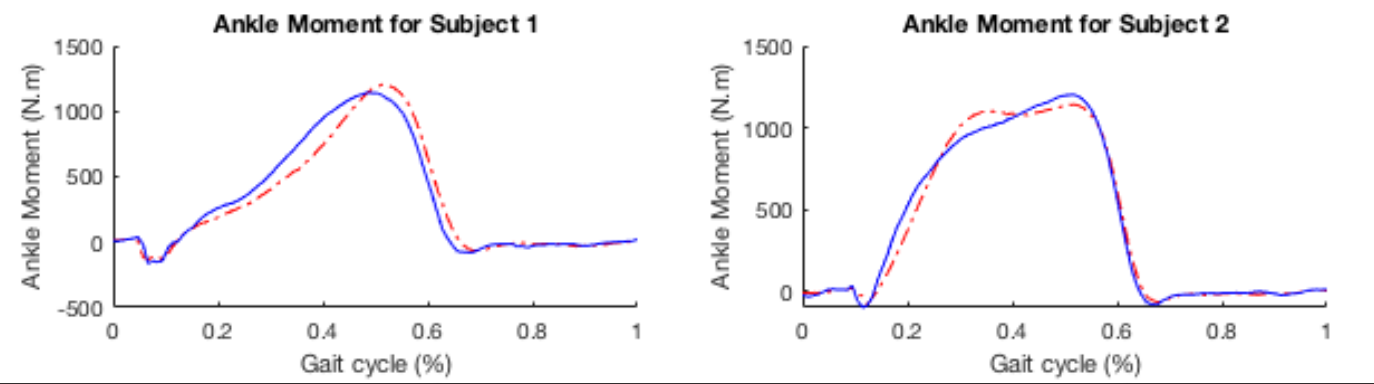


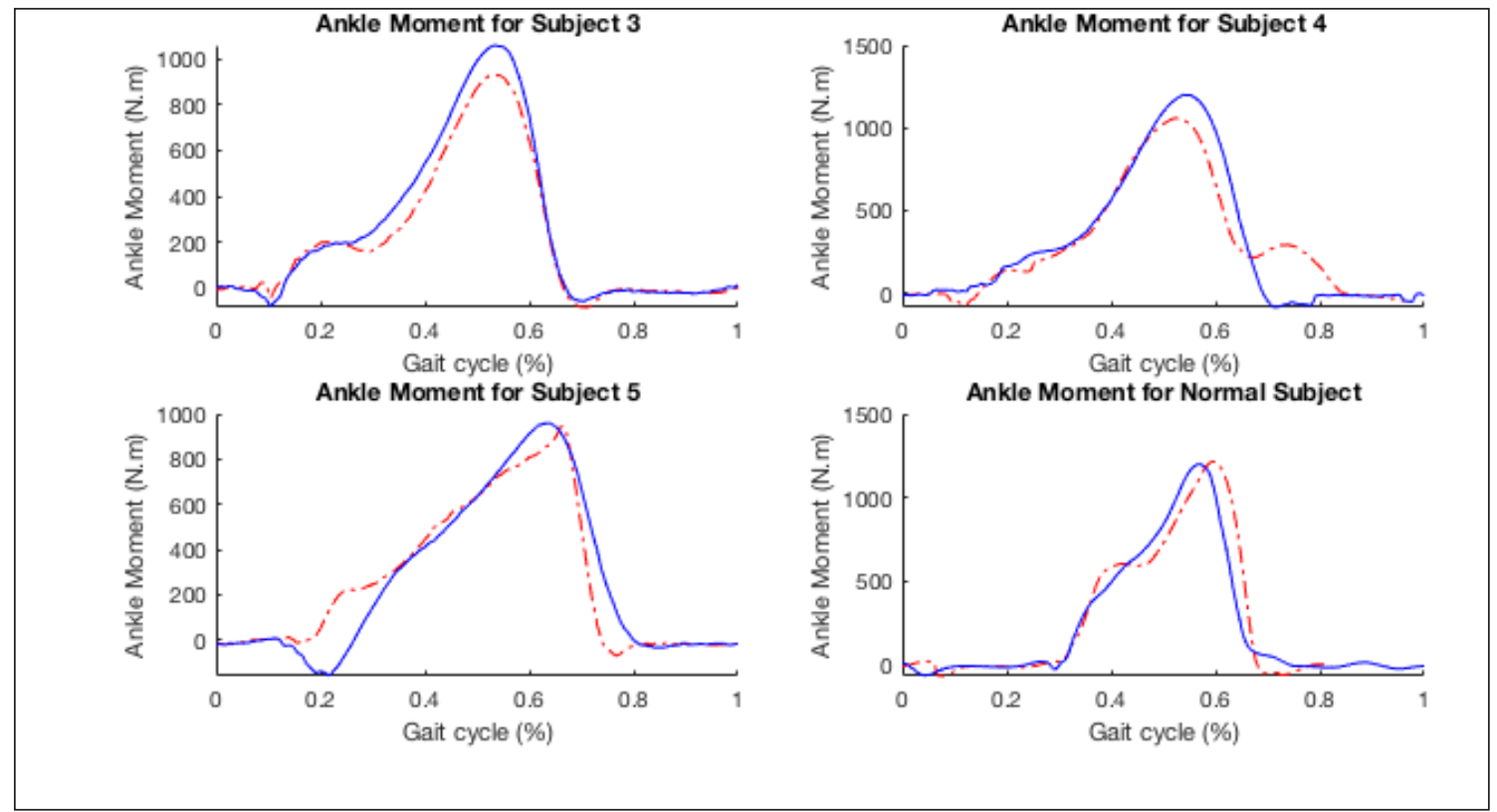

FIGURE 3. Graph of ankle joint moment for a complete gait cycle of all subjects

TABLE 3. Statistical analysis of ankle joint

\begin{tabular}{|c|c|c|c|c|c|c|c|c|}
\hline \multicolumn{9}{|l|}{ ANOVA } \\
\hline \multicolumn{2}{|c|}{ Source of variation } & SS & $\mathrm{df}$ & MS & $\mathrm{F}$ & $P$-value & F crit & Standard \\
\hline \multirow[t]{3}{*}{$\begin{array}{l}\text { Between } \\
\text { groups }\end{array}$} & $\begin{array}{l}\text { Right } \\
\text { foot }\end{array}$ & 4648.226 & 4 & 1162.056 & 13.6531163 & 0.00000000013815 & 2.389313144 & 2.88 \\
\hline & Left & 7974.883 & 4 & 1993.721 & 23.12612 & 0.000000000000000014859 & 2.389766936 & 2.85 \\
\hline & Foot & & & & & & & \\
\hline
\end{tabular}

\section{DISCUSSION}

Excessive pronation during the gait cycle can also increase the tibia-fascia traction especially during running, due to the contraction of superficial and deep ankle plantarflexors during stance phase in order to counteract the excessive pronator motion of the foot (Bandholm et al. 2008). To investigate the pattern of walking, motion analysis was done to identify the movement of the foot frame by frame while observing the motion, kinematic and kinetic such as the ankle angle, moment, power, and force acting on the joint during one complete gait cycle. This enables physicians to further investigate the joint motion and assist in determining the orthotic recommendation or modification to the subject with over pronated foot for proper treatment.

One complete gait cycle consists of the stance phase representing $60 \%$ of the gait cycle graph and the swing phase representing $40 \%$ of the graph. First, the kinetic parameter was the ground reaction forces (GRF) that develops during the gait cycle due to the force applied to the ground when the foot makes contact to it. There were three main components of GRF during a gait cycle which are vertical force, anterior/posterior force and medial/ lateral forces (Kluitenberg et al. 2012). Vertical force was 
the largest component on the GRF where the first peak represents the acceleration of the body's center of mass in the vertical direction during locomotion as it supports the weight, while the second peak is the propulsive phase of the GRF (Layton et al. 2018). The maximum vertical force can reach $120 \%$ of body weight during double stance and drop to 80 of body weight during single stance (Ryu \& Park 2018).

It results from BW and shear forces due to friction between the foot and the ground. Thus, as body weight is acting downward, it will generate an equal and opposite upward ground reaction. The GRF were higher during heel strike as the whole body weight was applied on the heel and then the GRF will drop during the mid-stance because the force applied on the foot is over larger area compared to during the heel strike as shown in Figure 4.
Subject 5 had higher dropping vertical GRF which was about $0.84 \mathrm{kN}$ compared to normal value $0.80 \mathrm{kN}$. This happened because of the excessive body weight of the subject causing the increase of force on contact to the ground during gait. As concluded by Shultz et al. (2017), the double differentiation of the body's center of mass was equal to the main vertical GRF parameters. The vertical GRF can be reduced by adding an insole because it can add a cushioning area and lengthen the time impact and contact of heel and toes toward the ground during walking (Alam et al. 2017). The p-values when comparing the subjects for normal foot condition with over-pronation foot condition were less than 0.05 . This shows that there were significant differences between these two groups.

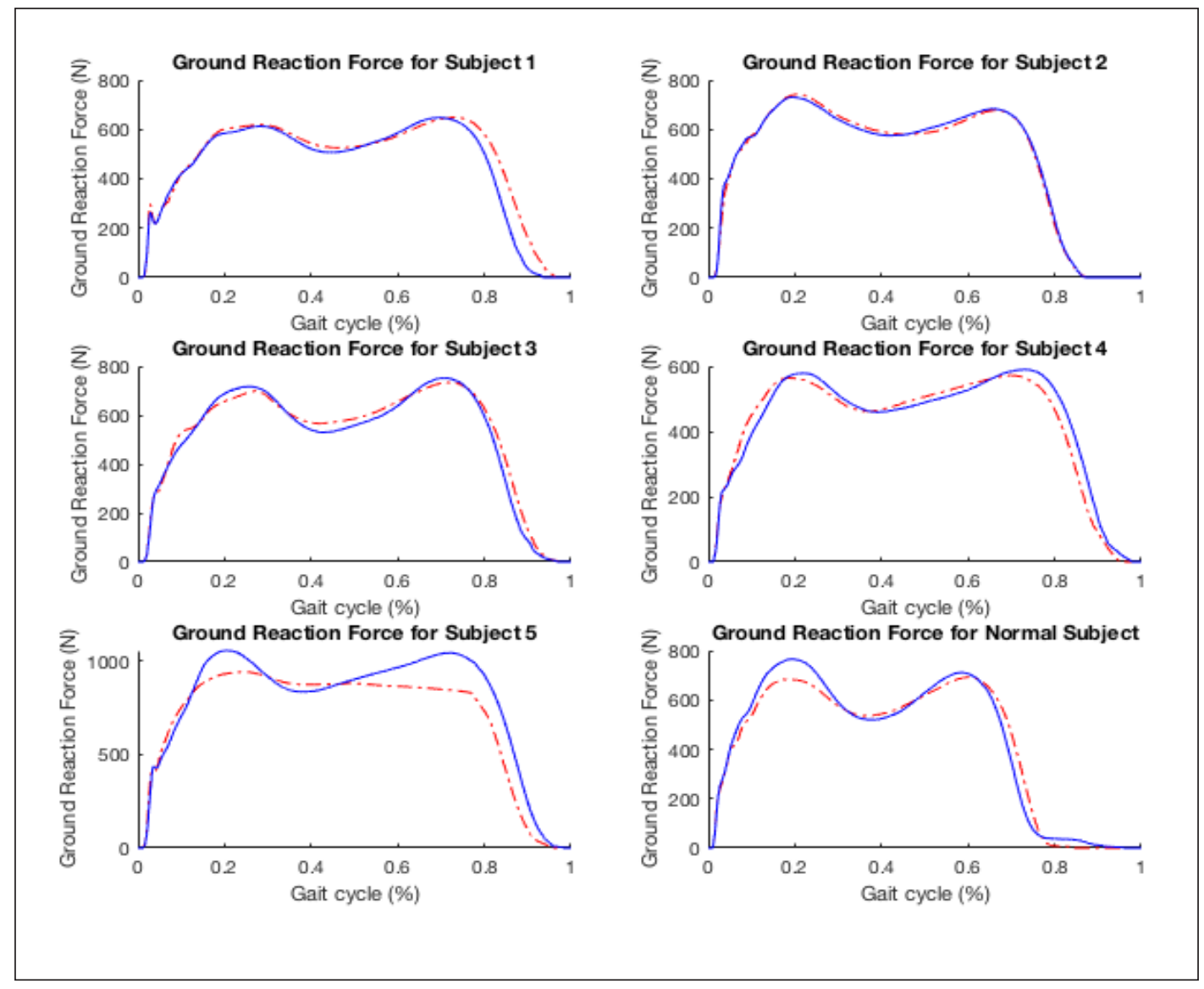

FIGURE 4. Graph of Ground Reaction Force for a complete gait cycle of all subjects

Second, the kinematic measurement observed was the range of motion, ROM, of the ankle joint during the gait cycle. The movement of the ankle joint was very important because it allows for shock absorption during the heel strike, progression of the body forward during the stance phase, and most importantly for push off before the toes leave the ground during the stance phase. During the swing phase, it functions as the foot clears from the ground. For the ROM, there were 4 phases that needed to be considered. First was phase 1, known as 
initial contact or heel strike. During this time, the ankle joint is in the neutral position. Then it begins to plantar flex between -3 and $5^{\circ}$ until the foot transfers into the next phase which foot flat. At this phase, the dorsiflexion muscles in the anterior compartment of the foot and ankle which is the tibialis anteriorly contract eccentrically to control the plantar flexion of the foot. This similar to the effects of a shock absorber and will help to smoothen the weight transfer to the lower limb (Hajirezaei et al. 2017). During this phase, subject 3 shows a $9.59^{\circ}$ at left foot but at normal range at right side that is $3.66^{\circ}$. This may be due to severe flat foot condition which leads to the subject having difficulty controlling the foot during heel strike, thus, increase the ankle angle and jump to the second phase. Then, follow with the loading response in which the maximum plantar flexion loading response happened, the range of normal ankle joint during this movement is in between $-5^{\circ}$ and $3^{\circ}$. By comparing with the normal subject, subject 1 , subject 2 , and subject 4 excessively plantar flex their foot since the angle is more than $-5^{\circ}\left(-9.61^{\circ},-5.39^{\circ}\right.$ and $-9.25^{\circ}$, respectively). Support from the study by Levinger et al. (2010) proved that the over pronated group shows significantly greater forefoot plantar flexion during late stance which is $-13.78^{\circ} \pm 5.6$. Since the left foot shows higher ankle angle, the right foot will compensate by reducing the ankle angle. During this phase the power acting on the joint was negative because the body is absorbing the energy to elongate the muscle, which is why all the subjects' ankle joint power was below $1.0 \mathrm{~W} / \mathrm{kg}$ during this phase as shown in Figure 5.

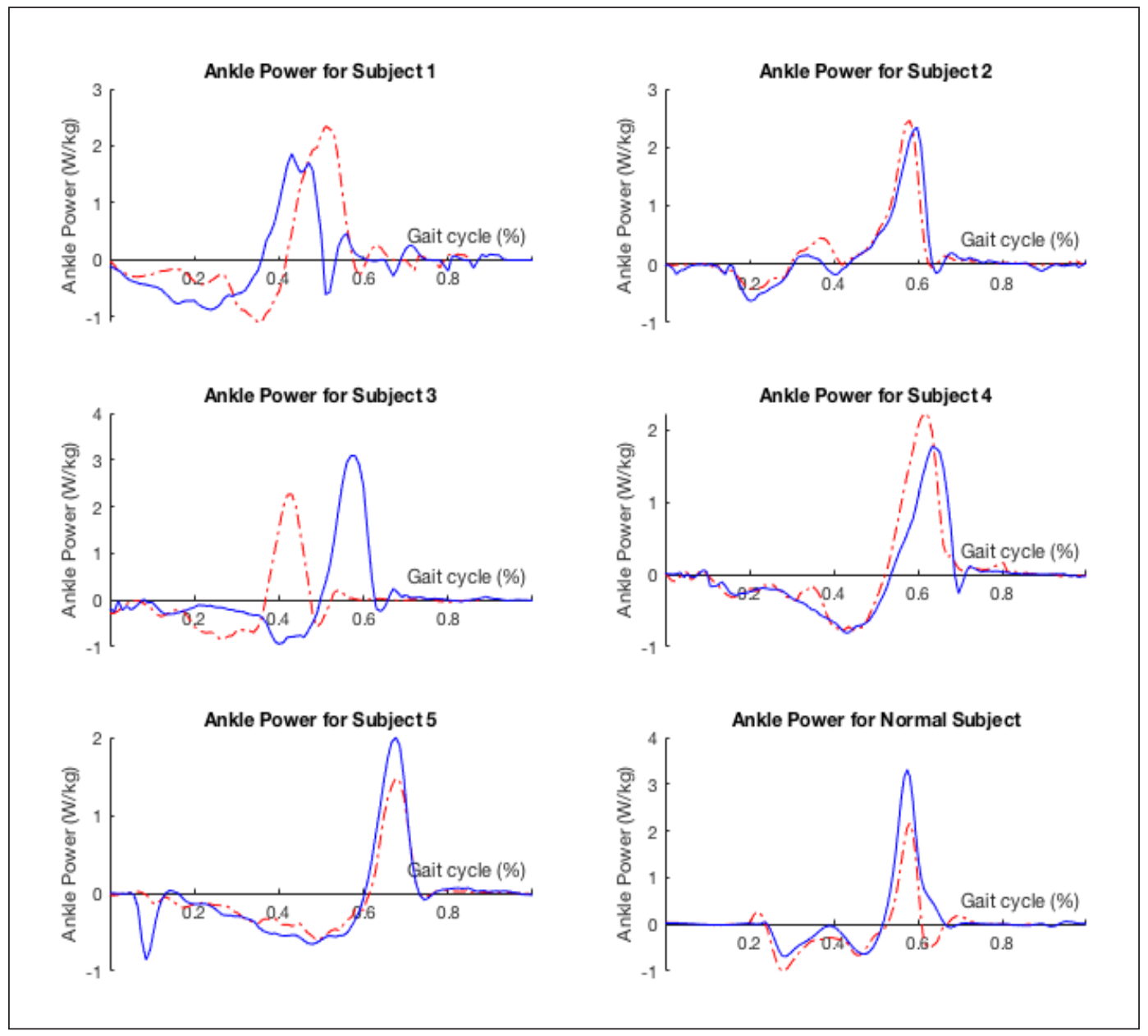

FIGURE 5. Graph of ankle power for a complete gait cycle of all subjects

For phase 2, the foot is in the flat condition, and the ankle begins dorsiflexion. The tibia plays an important role of moving while the foot remains stationary. The joint can reach a maximum of $10^{\circ}$ to $20^{\circ}$ when the tibia 
moves over the ankle joint. At this time the plantar flexor muscle contracts eccentrically to control the movement of the tibia forward. At this phase, the power is still in the negative power phase. Phase 2, subject to show less dorsiflexion angle compare to normal subject that were $6.83^{\circ}$ and $8.88^{\circ}$. Meanwhile, other subjects show higher values of dorsiflexion angle compared to normal subject. This was because the joint needed to have a bigger rocker system to support the foot in order to move it forward since the arch of the subjects cannot support it due to the flat foot condition and the joint was in an inward position.

During phase 3 , the flexion at toe off happened and the normal angle for flexion is around $-5^{\circ}$ as shown by the normal subject. All over pronated subjects show the angle of flexion bigger than $-5^{\circ}$. This happened because of the over pronation of foot having lower medial longitudinal arch that causes the foot to become flat. Thus, the muscle cannot help to control the movement of the foot during plantar flexion, making the ankle angle more than $-5^{\circ}$. This result was supported by a study that stated the plantar flexion angle for a flat foot was more than $-23^{\circ}$ (Banwell et al. 2018). At this phase, the plantar flexor muscle in the posterior compartment known as gastrocnemius contracts concentrically in order to push the foot into plantar flexion, propelling the body forward. This is where the start of the positive power phase happens as our body generates energy through the concentric muscle activity (Wang \& Brown 2017).

Last is phase 4, which is the swing phase of the gait cycle and where the joint will move in a dorsiflexion movement in order to clear the foot from the ground. During the dorsiflexion movement, the muscle contracts concentrically in order to provide foot clearance and readies for next foot strike. The joint angle at this phase was between $3^{\circ}$ and $5^{\circ}$. All subjects exceeded the normal ROM of joint at this phase, because the joint tried to stabilize the body and prepare for the following strike. It is reasonable for the swing ankle angle to have a bigger range in order to have higher walking stability and a lower initial walking speed for the next strike (Zang et al. 2016).

From the statistical analysis, the $P$-value was less than 0.05 and the variance ratio was more than 1 . It can be concluded that there was a significant difference between the groups, thus, the null hypothesis was rejected. Even though all the subjects presented over pronated foot, each subject will have a variance pattern of gait and ankle angle depending on the condition of the foot.

Therefore, a suitable arch support or insole that can support the medial side of the foot can be prescribed to the subjects, but the thickness of the insole depends on the condition of the subject. This medial support insole can help in stabilizing the joint during the initial phase, thus reducing the force acting on the joint (Kosonen et al. 2017). Furthermore, including ankle joint immobilization and plantar massage in therapy session improvement in the clinician-oriental balance outcome for all the subjects (Wikstrom \& McKeon 2017). By knowing the condition and grade of ankle for each subject, proper adjustment can be made for the rehabilitative training (Xiao et al. 2017). Thus, using the data from this study, proper method for the exercise can be introduced to help correct the deformities. This study limitation was the number of the subjects is small and need to be increased in future study.

\section{CONCLUSION}

In conclusion, all subjects had an over pronated foot condition in which the foot was in flat condition due to lower or medial longitudinal arch that caused the foot to become flat. This condition can lead to more serious problems such as unstable subtalar joint because of the alignment and position of joint rolling inward to the body. Each kinetic and kinematic parameter that was observed in this experiment indicated that the joint was trying to counteract the movement that happens during the gait cycle by increasing the ankle joint angle and muscle power. Therefore, it is suggested that subjects having over pronated foot to have a proper custom-made insole that is suitable to the condition and flexibility of the foot. The insole can help in reducing the force that act on the medial side of the foot by counteracting it using the cushioning mechanism of the insole.

\section{ACKNOWLEDGEMENTS}

This work was supported by the University of Malaya (RF016A-2018) and (MRUN 1). The author(s) declared no conflict of interest during conducting this research.

\section{REFERENCES}

Aguilar, M.B., Abián-Vicén, J., Halstead, J. \& Gijon-Nogueron, G. 2016. Effectiveness of neuromuscular taping on pronated foot posture and walking plantar pressures in amateur runners. Journal of Science and Medicine in Sport 19(4): 348-353.

Alam, M.N., Garg, A., Munia, T.T.K., Fazel-Rezai, R. \& Tavakolian, K. 2017. Vertical ground reaction force marker for Parkinson's disease. PloS ONE 12(5): e0175951.

Bandholm, T., Boysen, L., Haugaard, S., Zebis, M.K. \& Bencke, J. 2008. Foot medial longitudinal-arch deformation during quiet standing and gait in subjects with medial tibial stress syndrome. The Journal of Foot and Ankle Surgery 47(2): $89-95$.

Banwell, H.A., Paris, M.E., Mackintosh, S. \& Williams, C.M. 2018. Paediatric flexible flat foot: How are we measuring it and are we getting it right? A systematic review. Journal of Foot and Ankle Research 11(1): 21. 
Bibrowicz, K., Szurmik, T., Michnik, R., Wodarski, P., Myśliwiec, A. \& Mitas, A. 2018. Application of Zebris dynamometric platform and arch index in assessment of the longitudinal arch of the foot. Technology and Health Care 26(S2): 543551.

Golightly, Y.M., Hannan, M.T., Dufour, A.B., Hillstrom, H.J. \& Jordan, J.M. 2014. Foot disorders associated with overpronated and oversupinated foot function: The Johnston County osteoarthritis project. Foot \& Ankle International 35(11): 1159-1165.

Hagen, M., Lemke, M. \& Lahner, M. 2018. Deficits in subtalar pronation and supination proprioception in subjects with chronic ankle instability. Human Movement Science 57: 324-331.

Hajirezaei, B., Mirzaei, S. \& Khezri, A. 2017. The relationship between flat feet and cavus foot with body mass index in girl students. International Journal of Applied Exercise Physiology 6(3): 15-22.

Hintermann, B. 1999. Biomechanics of the unstable ankle joint and clinical implications. Medicine and Science in Sports and Exercise 31(7 Suppl): S459-S469.

Kakihana, W., Torii, S., Akai, M., Nakazawa, K., Fukano, M. \& Naito, K. 2005. Effect of a lateral wedge on joint moments during gait in subjects with recurrent ankle sprain. American Journal of Physical Medicine \& Rehabilitation 84(11): 858-864.

Kluitenberg, B., Bredeweg, S.W., Zijlstra, S., Zijlstra, W. \& Buist, I. 2012. Comparison of vertical ground reaction forces during overground and treadmill running. A validation study. BMC Musculoskeletal Disorders 13(1): 235.

Kosonen, J., Kulmala, J.P., Müller, E. \& Avela, J. 2017. Effects of medially posted insoles on foot and lower limb mechanics across walking and running in overpronating men. Journal of Biomechanics 54: 58-63.

Koura, G.M., Elimy, D.A., Hamada, H.A., Fawaz, H.E., Elgendy, M.H. \& Saab, I.M. 2017. Impact of foot pronation on postural stability: An observational study. Journal of Back and Musculoskeletal Rehabilitation 30(6): 1327-1332.

Krähenbühl, N., Horn-Lang, T., Hintermann, B. \& Knupp, M. 2017. The subtalar joint: A complex mechanism. EFORT Open Reviews 2(7): 309-316.

Layton, R.B., Stewart, T.D., Harwood, P. \& Messenger, N. 2018. Biomechanical analysis of walking gait when simulating the use of an Ilizarov external fixator. Proceedings of the Institution of Mechanical Engineers, Part H: Journal of Engineering in Medicine 232(6): 628-636.

Lee, J.S., Kim, K.B., Jeong, J.O., Kwon, N.Y. \& Jeong, S.M.J.A. 2015. Correlation of foot posture index with plantar pressure and radiographic measurements in pediatric flatfoot. Annals of Rehabilitation Medicine 39(1): 10-17.

Levinger, P., Murley, G.S., Barton, C.J., Cotchett, M.P., McSweeney, S.R. \& Menz, H.B. 2010. A comparison of foot kinematics in people with normal-and flat-arched feet using the Oxford Foot Model. Gait \& Posture 32(4): 519-523.

Mitchell, A., Dyson, R., Hale, T. \& Abraham, C. 2008. Biomechanics of ankle instability. Part 1: Reaction time to simulated ankle sprain. Medicine and Science in Sports and Exercise 40(8): 1515-1521.

Redmond, A.C., Crane, Y.Z., Menz, H.B. 2008. Normative values for the foot posture index. Journal of Foot and Ankle Research 1(1): 6.
Ringleb, S.I., Dhakal, A., Anderson, C.D., Bawab, S. \& Paranjape, R. 2011. Effects of lateral ligament sectioning on the stability of the ankle and subtalar joint. Journal of Orthopaedic Research 29(10): 1459-1464.

Riskowski, J.L., Dufour, A.B., Hagedorn, T.J., Hillstrom, H.J., Casey, V.A. \& Hannan, M.T. 2013. Associations of foot posture and function to lower extremity pain: Results from a population-based foot study. Arthritis Care \& Research 65(11): 1804-1812.

Rome, K. \& Brown, C. 2004. Randomized clinical trial into the impact of rigid foot orthoses on balance parameters in excessively pronated feet. Clinical Rehabilitation 18(6): 624-630.

Ryu, H.X. \& Park, S. 2018. Estimation of unmeasured ground reaction force data based on the oscillatory characteristics of the center of mass during human walking. Journal of Biomechanics 71: 135-143.

Sabharwal, R. \& Singh, S. 2017. Foot postural deviations in female Kathak dancers. International Journal of Physiotherapy 4(1): 38-43.

Shaliza Mohd Shariff, Thamilvaani Manaharan, Asma Ahmad Shariff \& Amir Feisal Merican. 2017. Evaluation of foot arch in adult women: Comparison between five different footprint parameters. Sains Malaysiana 46(10): 18391848.

Shih, Y.F., Wen, Y.K. \& Chen, W.Y. 2011. Application of wedged foot orthosis effectively reduces pain in runners with pronated foot: A randomized clinical study. Clinical Rehabilitation 25(10): 913-923.

Shultz, S.P., Song, J., Kraszewski, A.P., Hafer, J.F., Rao, S., Backus, S., Hillstrom, R.M. \& Hillstrom, H.J. 2017. An investigation of structure, flexibility, and function variables that discriminate asymptomatic foot types. Journal of Applied Biomechanics 33(3): 203-210.

Suresh, K. \& Chandrashekara, S. 2012. Sample size estimation and power analysis for clinical research studies. Journal of Human Reproductive Sciences 5(1): 7-13.

Wang, H. \& Brown, S.R. 2017. The effects of total ankle replacement on ankle joint mechanics during walking. Journal of Sport and Health Science 6(3): 340-345.

Wikstrom, E.A. \& McKeon, P.O. 2017. Predicting balance improvements following STARS treatments in chronic ankle instability participants. Journal of Science and Medicine in Sport 20(4): 356-361.

Willems, T., Witvrouw, E., Delbaere, K., De Cock, A. \& De Clercq, D. 2005. Relationship between gait biomechanics and inversion sprains: A prospective study of risk factors. Gait \& Posture 21(4): 379-387.

Wright, I.C., Neptune, R.R., Van Den Bogert, A.J. \& Nigg, B.M. 2000. The effects of ankle compliance and flexibility on ankle sprains. Medicine and Science in Sports and Exercise 32(2): 260-265.

Xiao, J., Zhang, Y., Zhao, S. \& Wang, H. 2017. Measuring the 3D motion space of the human ankle. Technology and Health Care 25(S1): 219-230.

Zang, X., Liu, X., Liu, Y., Iqbal, S. \& Zhao, J. 2016. Influence of the swing ankle angle on walking stability for a passive dynamic walking robot with flat feet. Advances in Mechanical Engineering 8(3): 1-13. 
Nur Saibah Ghani, Nasrul Anuar Abd Razak* \& Juliana Usman Department of Biomedical Engineering

Faculty of Engineering

University of Malaya

50603 Kuala Lumpur, Federal Territory

Malaysia
H. Gholizadeh

The Okinawa Rehabilitation Institute

Canada

*Corresponding author; email: nasrul.anuar@um.edu.my

Received: 9 April 2019

Accepted: 22 March 2020 